\title{
Quaternary Sediment Characteristic of Floodplain Area: Study Case at Kampar River, Rumbio Area and Surroundings, Riau Province
}

\author{
Yuniarti Yuskar ${ }^{1} *$, Dewandra Bagus Eka Putra ${ }^{1}$, M. Revanda ${ }^{1}$ \\ ${ }^{1}$ Department of Geological Engineering, Universitas Islam Riau, JI. Kaharudding Nasution No 113 Pekanbaru, 28284, Indonesia.
}

*Corresponding author : yuniarti_yuskar@eng.uir.ac.id

Tel.: +62-821-6935-4941

Received: Oct 1, 2016. Revised : 15 Nov 2016, Accepted: Nov 20, 2016, Published: 1 Dec 2016 (Filled by editor)

DOI: $10.24273 /$ jgeet.2018.3.1.1226

\begin{abstract}
The study area is located in some floodplains of meandering river environment along the Kampar River, Rumbio. Typical morphology of meandering river that found in this area can be classified as stream channel, floodplain, abandoned channel, and sand bars deposit. Meandering river system carries sediment supply by suspended and bed - load (mixed load) in conjunction with low energy into a particular characteristic on sediment deposition. This study aims to determine the characteristics of the sediments, changes in vertical and lateral spread of sediment deposition on the floodplain environment. This study conducted by field survey using a hand auger of $1.5 \mathrm{~m}-4 \mathrm{~m}$ depth and trenching which is a layer that has been exposed of 1-2 meters depth. Further analysis had been carried out using granulometri method and core data analysis to determine the characteristics and depositional facies. Sediment deposit that formed along the Kampar River is the result of the main channel migration of Kampar River. The characteristic of quaternary sediment facies is coarse to gravelly sand on the bottom followed by fine to very fine sand with pattern fining upwards and silt to clay and abundant terrestrial organic matter at the uppermost layer. Depositional facies are determined based on the characteristics of sediment facies which can be grouped into a stream channel, oblique accretion deposits, sand bars and overbank deposits.
\end{abstract}

Keywords: Quaternary Sediment, floodplain, facies, Meander River, Kampar

\section{Introduction}

The problem of quantitatively characterizing the plan geometry of meandering stream channels has intrigued engineers and earth scientists for more than 80 years (Michael P. O'neill And Athol D. Abrahams, 1986). A meander was formed by the continuous erosion process at the river bank as a result of river bend. Meandering river was transported and deposited by suspended and bedload (mixed load) process which characterized as low energy. The bedload is carried by the flow in the channel, with the coarsest material carried in the deepest parts of the channel. Finer bedload is also carried in shallower parts of the flow and is deposited along the inner bend of a meander loop where friction reduces the flow velocity (Nichols, 2009). Types of sediment that formed by meandering pattern are channel deposit, point bar, natural leeve, floodplain, oxbow lake, and crevasse splay (Yuskar and Choanji, 2017).

The study area is located in some floodplains of meandering river environment along the Kampar River, Rumbio. Typical morphology of meandering river that found in this area can be classified as stream channel, floodplain, abandoned channel, and sand bars deposit.

Floodplains have received considerable attention in recentvyears because of the valuable social and ecological functions of these systems, such as flood control, sediment and nutrient retention, recreational opportunities, timber production, and wildlife habitat (Pierce and King, 2008). Erosion from the banks of meandering rivers causes a local influx of sediment to theriver channel (Lauer and Parker, 2008).

Understanding the time scales and pathways for response and recovery of rivers and floodplains to episodic changes in erosion and sedimentation has been a long standing issue in fluvial geomorphology (Knox, 2006). Floodplains are dynamic feature that co-evolve with channel so at the present time there is no universal theory that available to predict floodplain width in natural rivers (as a function of drainage area, bank-full discharge, or sediment flux, etc) because floodplain morphology dynamically integrates across these and the other factors, over some unconfined time interval in the environment history of the watershed (Belmont, 2011). 
Floodplain is a strip of land that borders a stream channel and that is normally inundated during seasonal floods. Sediment is transported over the flooding as bed load and suspended load during floods. The sediment comes from the main channel, the valley sides and the floodplain itself (Posamentier, Roger G.; Walker, 2006). Sediment of point bar deposited medium sand with good sorting and upwards fining couplets during flood events. Some flood channels become enlarged during floods, and may become the dominant channel (Wood et al., 2008). The relative contribution of a variety of accretion deposits to the formation of meandering river floodplains have been the subject of prolonged discussion in the geomorphological literature.

The geometry of river channels and their flow style are controlled by a complex interplay of factors, including discharge, slope, climate and vegetation, amongst others (Stanistreet et al., 1993).

This study aims to determine the characteristics of the sediments deposit in the floodplain area that is resulted from abandoned channel, oblique and lateral accretion deposits and sediment that was carried during flooding in its surrounding. Vertical changing and lateral deployment of sediment deposit on the floodplain area can also be seen by looking at the physic and biology characteristics of these sediments.

\section{Geological Setting}

One of the meandering river system in the Riau Province, Indonesia is the Kampar River. Kampar
River on the Sumatra Island in Indonesia originates in the mountainous Bukit Barisan of West Sumatra, and empties into the Malacca Strait on the island's eastern coast. The river is the confluence of two big tributaries, Kampar Kanan River and Kampar Kiri River. The tributaries meet in the Langgam subdistrict, Pelalawan Regency, before flowing into the Malacca Strait as the Kampar River. Koto Panjang, an artificial lake upstream of the river, is used to power a hydroelectric generating plant. The River has a lenght of $413 \mathrm{~km}$ and an average depth of $7.7 \mathrm{~km}$ and average width of $143 \mathrm{~m}$ (Yuskar and Choanji, 2017). Fluvial meander system developed typical oxbow lake morphology with tropical rain forest, sand bar and river with fishery product. It has been used as a local attraction (Yuskar, 2016); (Choanji et al., 2018).

Rumbio is a district in Kampar Regency with elevation ranging between 25 to $50 \mathrm{~m}$ above sea level. The landscape that developed in research area were channel, floodplain, natural leeve, point bars, abandoned channel, and oxbow lake. This area is gently sloping and the occurrence of heavy rainfall may cause flooding.

Sediment distribution in research area shows by quaternary age landforms. Along The Kampar Kanan River was deposited Young Alluvium (Qh) during Holocene aged that consist of gravels, sands and clays (Clarke, M.C.G; Kartawa, W.; Djunuddin, A.; Suganda, E.; Bagdja, 1982).
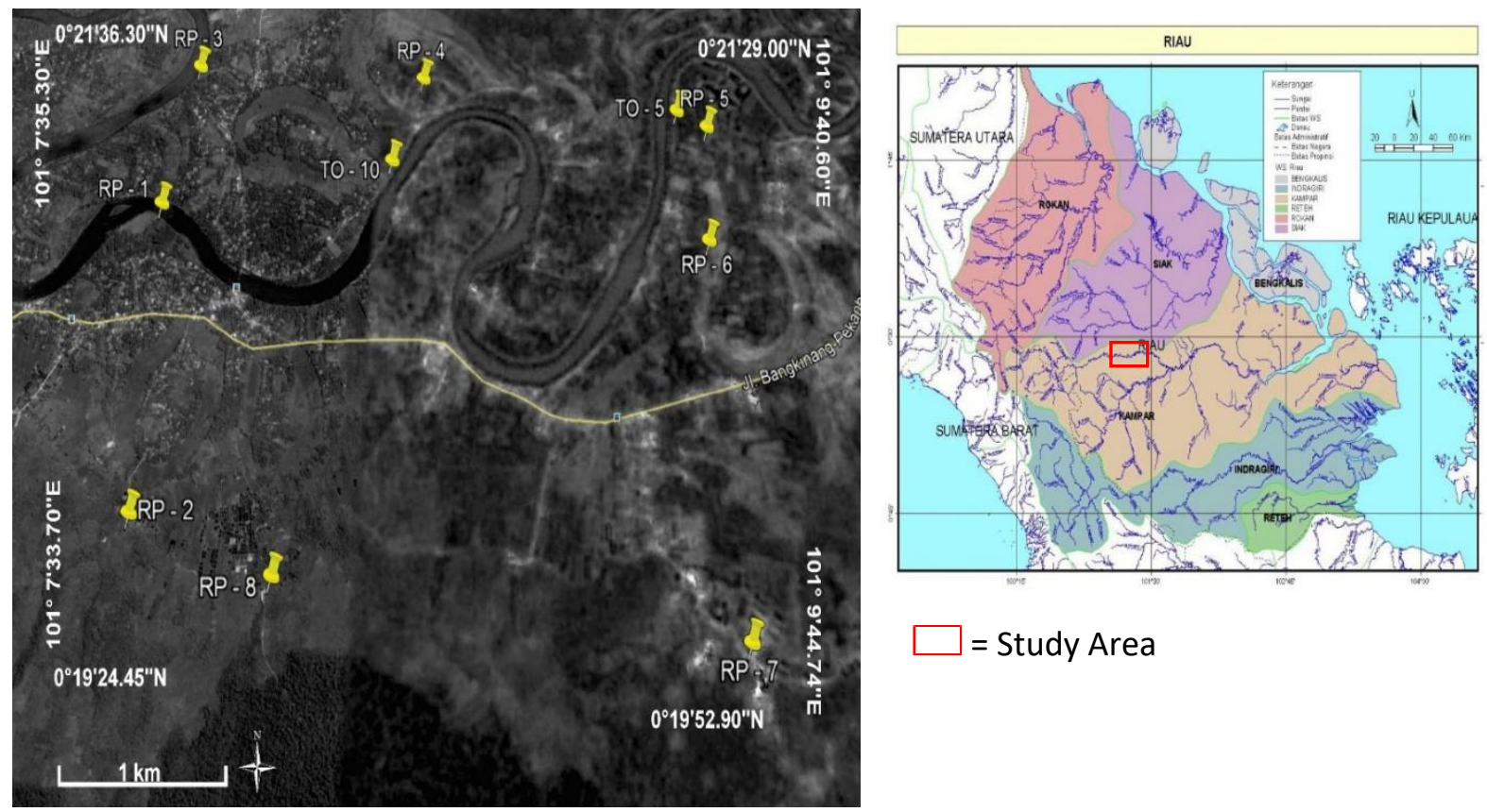

= Study Area

Fig. 1 Location of Study Areas 


\section{Methodology}

Field survey had been conducted to collect the data by using hand auger drilling in eight different points and trenching method in two localities (Fig.1). Laboratory analysis such as grain size analysis or sieve analysis,core analysis, and facies analysis had been carried out to obtain the result. The depths of drilling core ranging from 1.5 to $4 \mathrm{~m}$. Trenching was done around the drilling points to observed the sedimentary layers that had been exposed in the surface with 1-3m thickness. Grain size determination was done using sieve analysis method, mesh size $2.38 \mathrm{~mm}, 1.19 \mathrm{~mm}, 0.6 \mathrm{~mm}$, $0.297 \mathrm{~mm}, 0.149 \mathrm{~mm}$ and $0.074 \mathrm{~mm}$. The sample al so being described to identify the sediment characteristic up to depositional facies.

\section{Result and Discussion}

Morphological condition of the study area was flat ramp that lying on the floodplain and abandoned channel environment of Kampar River. The difference of physical and biological characteristic are the main parameters in determination of sedimentary facies. Sieve analysis result of core and trenching data shows coarse to gravelly sand at the bottom layer followed by fine to very fine sand with pattern fining upwards and silt to clay and abundant terrestrial organic matter at the uppermost layer.

There are three observed layers in TO-05 with $3.5 \mathrm{~m}$ thickness. Bottom layer $(0-50 \mathrm{~cm})$ have reddish brown color and coarse sand - vey coarse sand in grain. Second layer $(51-200 \mathrm{~cm})$ have blackish brown color, coarse sand - very coarse sand in grain and overgrown by plant roots. The uppermost layer $(201-350 \mathrm{~cm})$ is medium sand fine sand. The sedimentary layers at this locality shown fining upward changing in grain size (Fig.2).

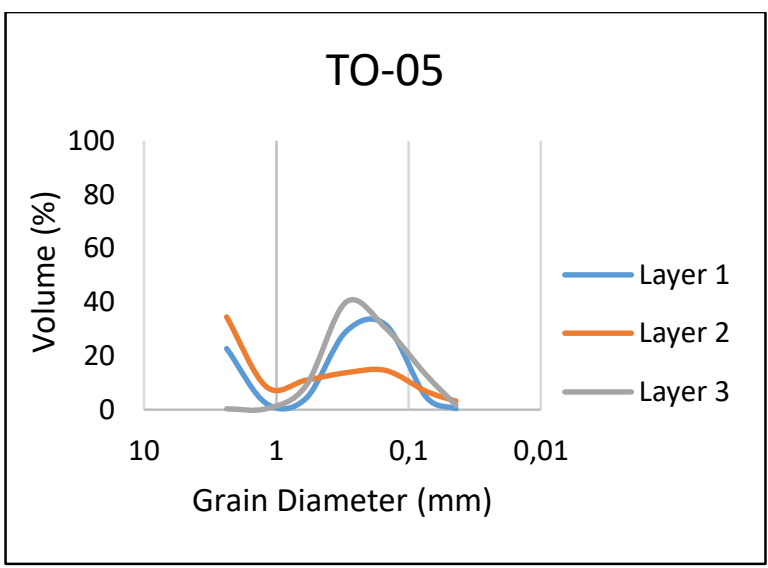

Fig 2. Sieve analysis shown the grain size percentage of each layer in TO-05.

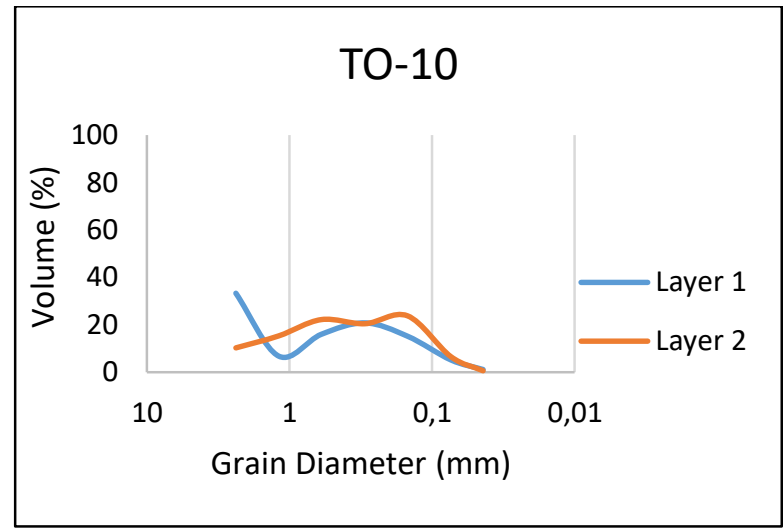

Fig 3. Sieve analysis shown the grain size percentage of each layer in TO- 10 .

Two sedimentary layers had been observed in TO-10. Bottom layer $(30 \mathrm{~cm}$ thick) has brownish grey weathered color and grey fresh color. Grain size distribute from silt to very fine sand and the plant roots was found in this layer. The upper layer ( $203 \mathrm{~cm}$ thick) has pebble to boulder floating grain size, brownish grey weathered color, grey fresh color and more plant roots compare to the lower layer.

There are three to seven sedimentary layers can be observed in TO-08 with thickness $10 \mathrm{~m}$ (Fig. 4). Bottom layer $(100 \mathrm{~cm}$ thick) have reddish grey weathered color and grey fresh colour, very fine sand to silt and ripple mark because of water flowing. Then, at top of the first layer were deposited clay sediment with reddish grey colour and paralel lamination sedimentary structure. After that, pebble coarse sand and fining up layer became fine sand. Then sicnificantly, thick layers of pebble coarse sand were deposited $(100 \mathrm{~cm}$ to $250 \mathrm{~cm}$ thick). Furthermore, the grain size sediment changing become fine to very fine sand with $250 \mathrm{~cm}$ thick and at the other part of the section, this layer have $550 \mathrm{~cm}$ thick. The colour of this layer is greyish white at the bottom layer and become reddish grey at the top layer is caused intensively weather. The toppest layer is soil with plant root.

\subsection{Sediment Facies}

Based on the sieve analysis result of core and trenching data (Fig.4) and from the core description (Fig.5), there are several sediment facies in this study area:

\section{Pebble coarse sand}

Coarse sand to pebble have blackish brown color and intercalation with thin reddish sand, resulting from the oxidation process. 

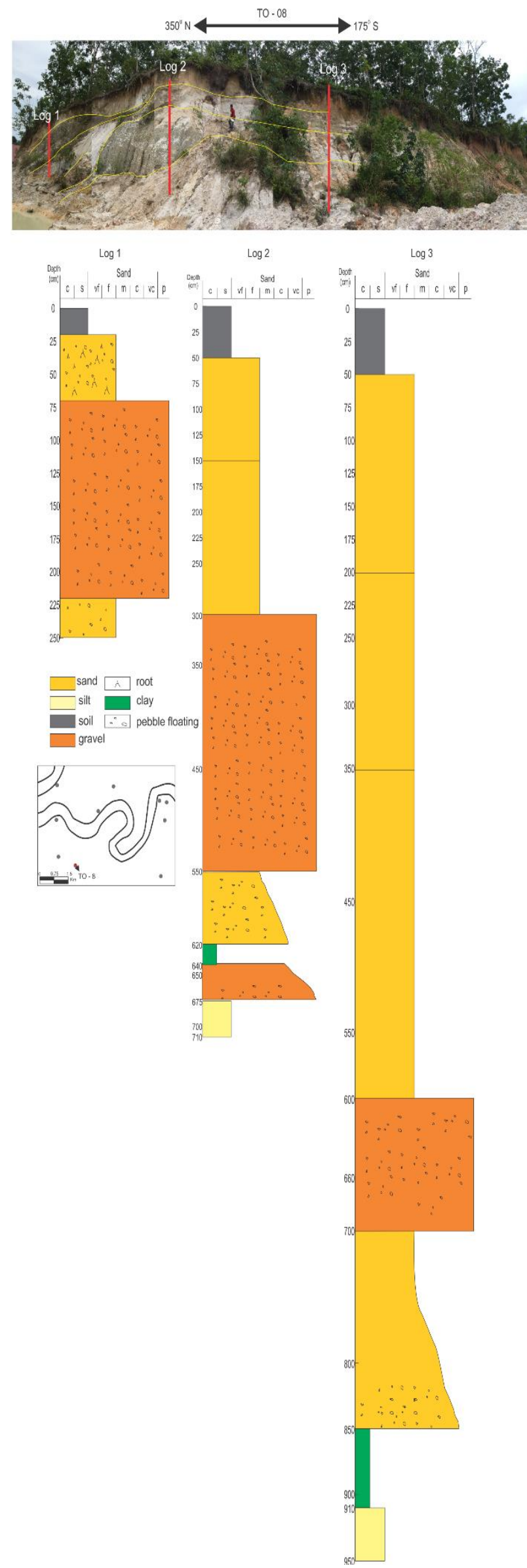

Fig. 4 Profile analysis of trenching data (TO-08)
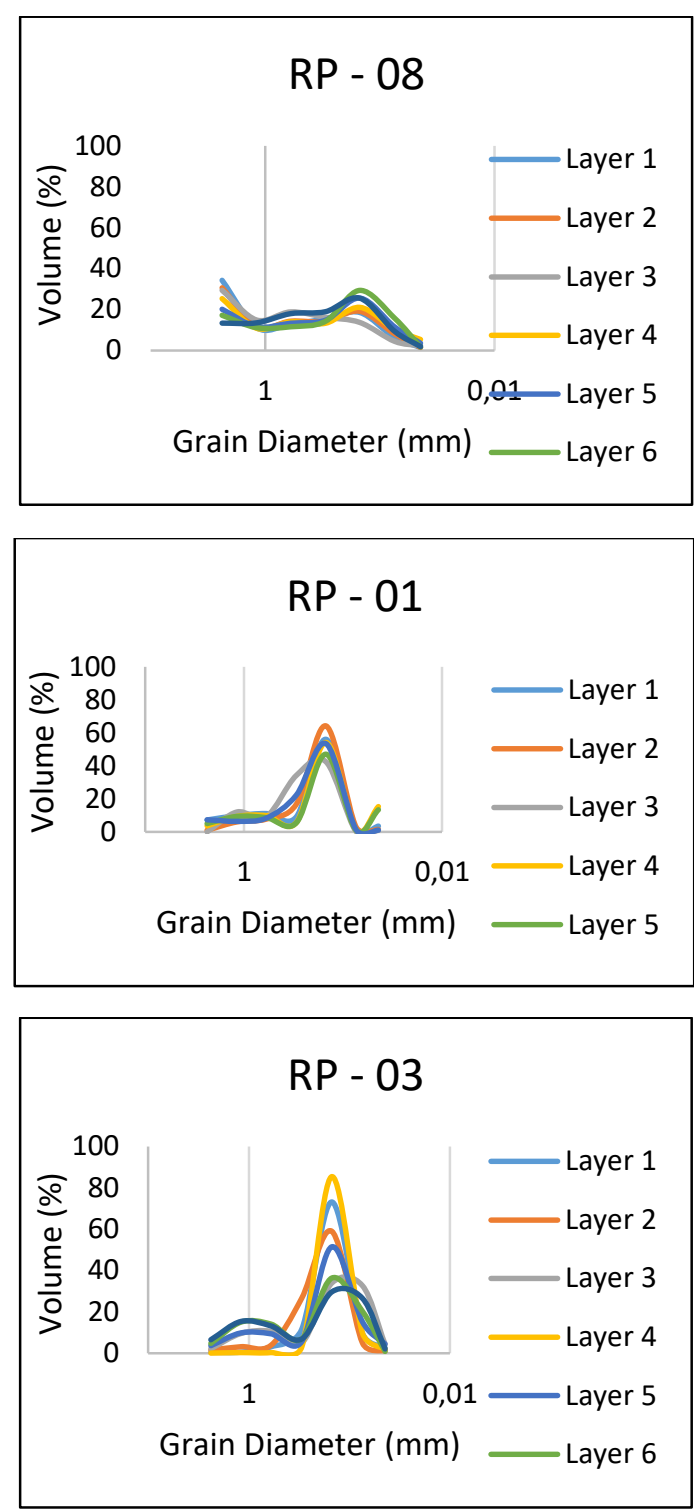

Fig. 5 Sieve analysis of drill core (RP-01, RP-03 and RP$08)$.

This facies was found in $150-145 \mathrm{~cm}$ depth at core RP-1, 250-220cm depth at core RP-2, 320$194 \mathrm{~cm}$ depth at core RP-5 and 350-261 depth at core RP-8.

2. Pebble coarse sand

Coarse sand to pebble have blackish brown color and intercalation with thin reddish sand, resulting from the oxidation process. This facies was found in $150-145 \mathrm{~cm}$ depth at core RP-1, $250-220 \mathrm{~cm}$ depth at core RP-2, 320-194cm depth at core RP-5 and 350-261 depth at core RP-8.

3. Silt to Clay intercalation with thin red sand Silt to clay sediment, greyish brown color was found in $145-120 \mathrm{~cm}$ depth at core RP-1. This layer intercalation with thin orange sand that contain Fe and had been oxidized.

4. Clay sediment

This lithofacies was found in $242-162 \mathrm{~cm}$ depth at core RP-7. Sediment deposit is black clay that 
rich in organic material or carbon and wood pieces.

5. Very Fine Sand with minor terrestrial organic matters

Brown very fine sand in $134-120 \mathrm{~cm}$ depth at RP- 1 , in 139-121 cm depth at RP-5. Intercalation of reddish orange sand and fine roots also found in this layer. The changing of color to grey is the characteristic of very fine sand at core RP- 6 in $264-179 \mathrm{~cm}$ depth.

6. Fine sand with terrestrial organic matters and oxidation

Fine grain sand, brownish color, presence of small plant roots and intercalation of red sand caused by the oxidation process. Found in 151$95 \mathrm{~cm}$ depth at core RP-3 and $92-42 \mathrm{~cm}$ depth at core RP- 5 but brownish grey color and without intercalation of reddish sand.

7. Silt with terrestrial organic matters

Silt with reddish orange color and overgrown by fine roots, found in $100-67 \mathrm{~cm}$ at core RP-3 and $22-0 \mathrm{~cm}$ at core RP-5, grey color. At core RP8 in $124-52 \mathrm{~cm}$ depth, blackish brown color, overgrown by fine roots and found the presence of floating pebble $(0.2-1 \mathrm{~cm}$ in size).

8. Clay with terrestrial organic matters Blackish brown clay with larger part of plant. Found in 51-25cm depth at core RP-3.

\subsection{Depositional Fasies}

Based on the sedimentary facies analysis of core and trenching data, the depositional facies can be categorize into channel deposit, oblique accretion deposit and overbank deposit (Fig. 6).

1. Channel deposit found at the bottom layer, characterized by fining up succession and constantly begin with coarse sand to pebble. Several sediment facies had been found such as pebble coarse sand, silt to clay with oxidation sand and clay sediment.

2. Oblique accretion deposit the drilling point was located in the river loop where the erosion occurred and deposition of lateral accretion deposit took place. This deposit characterized by fining up succession, fine sand - very fine sand in grain size and the sediment facies was very fine sand to fine sand with minor terrestrial organic matters.

3. Sand bar deposit this deposit characterized by coarsening up succesion, fine to medium sand in grain size and the sediment facies was fine sand with terrestrial organic matters and oxidation.

4. Overbank deposit sediment that carried by the flood and frequently outside of the channel. Deposited at the upper layer, silt to clay in grain size and overgrown by plant roots. Several sediment facies were found such as fine sand with terrestrial organic matters and oxidiation, silt with terrestrial organic matters, and clay with terrestrial organic matters.
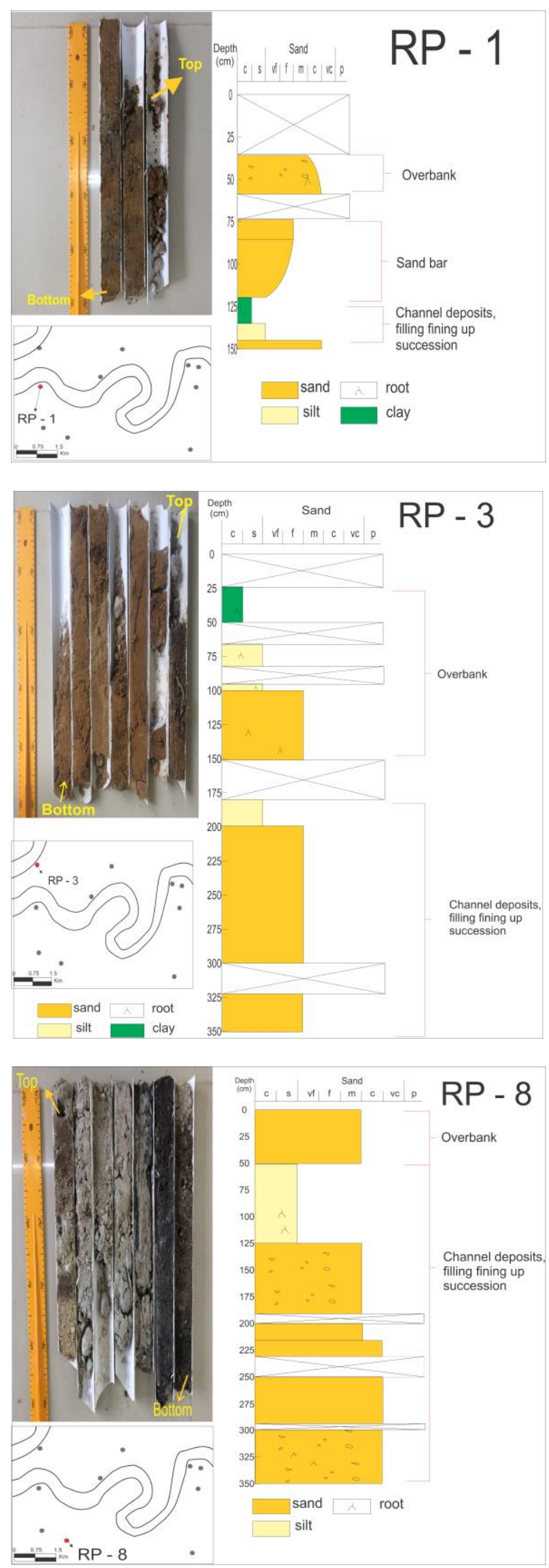

Fig. 6 Depositional facies analysis of core data (RP-01, RP03 and RP-08). 


\section{Conclusion}

The research area was a floodplain environment that formed as a result of multistory channel caused The author would like to say thanks to Lembaga Penelitian dan Pengabdian Kepada Masyarakat (LPPM) Universitas Islam Riau (UIR) for funding and support this research. We also say thanks to all Sedimentology and Hidrology laboratorium team member (Batara, Dilla Permata Sari, Peter Syahputra, Desi Wijayanti, Miftahul Jannah, Bayu Defitra, Tristan Aulia, Genta Rier, Muchtar Zafir, Sandi Masdrianto, Susilo and M. Iqbal) who help us in this research.

\section{REFERENCES}

Belmont, P., 2011. Floodplain width adjustments in response to rapid base level fall and knickpoint migration. Geomorphology 128, 92-101. doi:10.1016/j.geomorph.2010.12.026

Choanji, T., Rita, N., Yuskar, Y., Pradana, A., 2018. Connectivity Relationship of Fluid Flow On Deformation Band: Analog Study at Petani Formation, Riau, Indonesia. Bull. Sci. Contrib. Geol. 15, 193-198.

Clarke, M.C.G; Kartawa, W.; Djunuddin, A.; Suganda, E.; Bagdja, M. (1982). Geological Map of The Pakanbaru Quadrangle, Sumatra. PPPG.

Knox, J.C., 2006. Floodplain sedimentation in the Upper Mississippi Valley: Natural versus human accelerated. Geomorphology 79, 286-310. doi:10.1016/j.geomorph.2006.06.031

Lauer, J.W., Parker, G., 2008. Net local removal of floodplain sediment by river meander migration. Geomorphology 96, 123-149. doi:10.1016/j.geomorph.2007.08.003

Michael P. O'neill And Athol D. Abrahams, 1986. The problem of quantitatively characterizing the plan geometry of mean- dering stream channels has intrigued engineers and earth scientists for more than 80 yrs (Jefferson, 1902). J. Hydrol. 83 337--353 Elsevier Sci. Publ. B.V., Amsterdam -- Print. Netherlands [1l 83, 337-353.

Nichols, G., 2009. Sedimentology and stratigraphy, Journal of Chemical Information and Modeling. doi:10.1017/CBO9781107415324.004

Pierce, A.R., King, S.L., 2008. Spatial dynamics of overbank sedimentation in floodplain systems. Geomorphology 100, 256-268. doi:10.1016/j.geomorph.2007.12.008

Posamentier, Roger G.; Walker, H. W. (2006). Facies Models Revisited. (H. W. Posamentier, Roger G.; Walker, Ed.). SEPM Society for Sedimentary Geology.

Stanistreet, I.G., Cairncross, B., McCarthy, T.S., 1993. Low sinuosity and meandering bedload rivers of the Okavango Fan: channel confinement by vegetated levées without fine sediment. Sediment. Geol. 85, 135-156. doi:10.1016/0037-0738(93)90079-K

Wood, S.H., Ziegler, A.D., Bundarnsin, T., 2008. Floodplain deposits, channel changes and riverbank stratigraphy of the Mekong River area at the 14th-Century city of Chiang Saen, Northern Thailand. Geomorphology 101, 510-523. doi:10.1016/j.geomorph.2007.04.030

Yuskar, Y., 2016. Geo-tourism Potential of Sand Bars and Oxbow lake at Buluh. J. Geosci. Eng. Environ. Technol. 1, 59-62.

Yuskar, Y., Choanji, T., 2017. Uniqueness Deposit of Sediment on Floodplain Resulting From Lateral Accretion on Tropical Area : Study Case at Kampar River , Indonesia 2, 14-19. 